\title{
Antiparasitic Efficacy of Artemisia ludoviciana Nutt. (Asteraceae) Essential Oil for Acanthamoeba castellanii, Leishmania infantum and Trichomonas vaginalis
}

\author{
Ayşe Baldemir”, Ülkü Karaman², Selen IIlgün1, Gamze Kaçmaz², Betül Demirci ${ }^{3}$ \\ ${ }^{1}$ Erciyes University, Faculty of Pharmacy, Department of Pharmaceutical Botany, Kayseri, TURKEY. \\ ${ }^{2}$ Ordu University, Faculty of Medicine, Department of Medical Parasitology, Ordu, TURKEY. \\ ${ }^{3}$ Anadolu University, Faculty of Pharmacy, Department of Pharmacognosy, Eskişehir, TURKEY.
}

\begin{abstract}
Background: Artemisia ludoviciana Nutt. (Asteraceae) is an aromatic, herbaceous, perennial plant and known commonly name as "White Sage", "Black Sage", "Prairie Sage" or "Cudweed Sagewort". It is traditionally used as an antispasmodic, anthelminthic, antidiarrhoeal, stomachic, hepatic colic, appetizer, and regulator of menstruation, antimalaric and antiparasitic efficiancy. Objective: The essential oil composition of the flowering herb of $A$. ludoviciana $(\mathrm{AL})$ was investigated and for the first time, the oil was screened for antiparasitic activity. Methods: The chemical composition of the hydrodistilled essential oil (EO) obtained from the herb with flowered of $A$. ludoviciana was analyzed by Gas Chromatography-Flame Ionization Detector (GC-FID) and Gas Chromatography-Mass Spectrometry (GC-MS). Results and Discussion: The outcomes showed that the major components of oil were camphor $(40.6 \%), 1,8$-cineole $(25.5 \%)$ and camphene $(4.7 \%)$, among 45 identified compounds, comprising 98.5 of the total oil. In addition, the oil was tested against Acanthamoeba castellanii, Leishmania infantum and Trichomonas vaginalis. Conclusion: In this study, it is first demonstrated that A. Iudoviciana essential oil (AL-EO) is effective against three important parasites.
\end{abstract}

Key words: Artemisia ludoviciana, Camphor, 1,8-Cineole, Camphene, Antiparasitic effect, GC-FID, GC/MS.

\section{INTRODUCTION}

Plants/plant extracts and their active components have been used for many centuries as treatments for diseases from headaches to parasite infections. In the last 20-30 years, researchers have seriously focused on determining whether plant-derived traditional remedies are effective and what their mode of action is. Several studies proving the effects of plants on parasite infections have been undertaken using aqueous or alcoholic extracts and essential oils (EOs). ${ }^{1}$ The EOs generally have a broad spectrum of bioactivity, owing to the presence of several active ingredients or secondary metabolites, which work through various modes of action. ${ }^{2}$
The genus Artemisia L. comprises important medicinal plants, which have gained phytochemical attention due to their biological and chemical diversity, and essential oil production. Artemisia species, widespread throughout the world, are frequently used for the treatment of diseases such as malaria, hepatitis, cancer, inflammation and infections by fungi, bacteria and viruses. ${ }^{2}$ The genus Artemisia includes 23 perennial aromatic herbs and shrubs that grow wild in Turkey. ${ }^{3}$ In the literature, there are only a few papers dealing with the essential oil composition and properties of Artemisia ludoviciana Nutt. from among these
Submission Date: 18-08-2017; Revision Date: 12-10-2017; Accepted Date: 29-10-2017

DOI: 10.5530/ijper.52.3.48 Correspondence: Ayşe Baldemir, Assistant Prof., Department of Pharmaceutical Botany, Faculty of Pharmacy, Erciyes University, 38039 Kayseri, TURKEY.

Phone: +90-352-2076666 E-mail: aysebaldemir@gmail. com

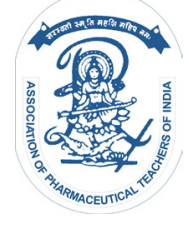

www.ijper.org 
species. Previous studies reported that main components of leaf oils of $A$. ludoviciana (AL) grown in USA and Mexico analyzed by gas chromatography-mass spectrometry (GC-MS) were alpha-pinene, camphene, 1,8-cineole, camphor, borneol, nonanal, linalool, carvacrol and p-alpha-dimethylbenzyl alcohol., ${ }^{4,5}$ The dried whole plant, a leaf infusion and essential oil (EO) of A. Indoviciana Nutt. have traditionally been used due to antispasmodic, anthelminthic, antidiarrhoeal, stomachic, hepatic colic, appetizer, regulator of menstruation, antimalarial, and antiparasitic activity. ${ }^{4,67}$ Hexane, acetone, methanol and aqueous extracts of $A$. ludoviciana were found to be active in vitro against the parasitic protozoa Entamoeba histolytica and Giardia lamblia. ${ }^{6}$

In Africa, Asia, Europe and South and North America, nearly 350 million people are at risk of leishmaniasis. ${ }^{8}$ Between 2000 and 2014 in Turkey a total of 413 cases were reported of visceral leishmaniasis (VL) infection due to the vector Leishmania infantum. There were 29,845 cases of cutaneous leishmaniasis (CL) due to the vector Leishmania tropica from 2000-2014. ' Treatment of the parasite uses antileishmanial medications like sodium stibogluconate, miltefosine, parmomycin, amfotericin B and pentamidine. ${ }^{10}$ However, the effects of these medications are limited and there are serious side effects including nephrotoxic, hepatotoxic and teratogenic effects. ${ }^{11,12}$ Globally and in Turkey, it has been reported that resistance has developed to the primary medication for treatment of CL and VL of five valuable antimony species, sodium stibogluconate (Pentostam ${ }^{\circledR}$ ) and megluminantiamoniate (Glucantime $\left.{ }^{\circledR}\right) .^{12-16}$ Due to the lack of an effective prophylactic against the disease, the toxic effects of currently-used medications and the increasing resistance to these medications, the necessity for discovery and development of new therapeutic agents has been reported. ${ }^{11,17,18}$

Trichomoniosis is a common infection everywhere in the world and the infection rates are reported to show great variations from country to country and society to society. Researchers have stated that the different results obtained by different people in different regions may be due to factors such as the use of different techniques for diagnosis, and deficient and mistaken assessments. ${ }^{19,20}$ Trichomonas may be treated with metronidazole, tinidazole, nimorazole, secnidazole and ornidazole. It is recommended to administer paired treatment at the same time. Metranidazole may be administered to resistant cases 4-6 weeks after first treatment. Patients developing side effects linked to metranidazole may be given agents like polyoxethylene nonylphenol, aminacrine, sodium edetate and docusate sodium for 2 weeks duration administered by the vaginal route twice per week..$^{21,22}$

Acanthamoeba species may proliferate easily in natural environments, infected organs, and on xenic and axenic cultures. Acanthamoeba have been identified in natural environments like water, thermal water, sea water, soil and air. Additionally they have been reported to be isolated from human-made environments such as drinking water, bottled spring water, distilled water in laboratories, chlorinated swimming pools and contact lens storage cases. $^{23-26}$

Granulamatous amoebic encephalitis (GAE) cases are commonly detected to involve Acanthamoeba culbertsoni, A. castellanii and A. rhysoides species. Acanthamoeba keratitis is a parasitosis caused by a variety of Acanthamoeba species. Preparatory factors are trauma, contact lens use, and contact of infected water with the cornea. It is observed in healthy individuals and causes severe ocular pain, burning, vision disruption and stromal infiltration with ring shape. Over time vision is impaired and the eye may even be lost. In Acanthamoeba keratitis cases, most commonly $A$. castellanii and $A$. polyphaga are identified. ${ }^{27,28}$ For treatment a variety of medications have been tried. Among effective agents, propamidine isethionate, ketoconazole, miconazole and itraconazole may be listed. Surgical cleaning of the lesion and additionally oral and local administration of miconazole have been emphasized as effective. ${ }^{29}$

In this study, $\mathrm{EO}$ of the A. ludoviciana flowering herb was analyzed with GC and GC-MS and antiparasitic efficacy of the oil against Acanthamoeba castellanii, Leishmania infantum and Trichomonas vaginalis was examined for the first time.

\section{MATERIALS AND METHODS}

\section{Plant material}

The flowering herb of $A$. ludoviciana was obtained from Zeytinburnu Medicinal Plant Garden, Istanbul, Turkey in 2016.

\section{Isolation of the essential oil}

The plant materials were air dried at room temperature and were subjected to hydrodistillation for $3 \mathrm{~h}$ using a Clevenger-type apparatus to extract essential oils. The oils were dried over anhydrous sodium sulfate to remove moisture and stored at $+4^{\circ} \mathrm{C}$ until analyzed and tested further. 


\section{Analysis of essential oil GC-MS analysis}

The GC-MS analysis was carried out with an Agilent 5975 GC-MSD system. An Innowax FSC column (60 m x $0.25 \mu \mathrm{mm}, 0.25 \mu \mathrm{m}$ film thickness) was used with helium as carrier gas $(0.8 \mathrm{ml} / \mathrm{min})$. The GC oven temperature was kept at $60^{\circ} \mathrm{C}$ for $10 \mathrm{~min}$ and programmed to $220^{\circ} \mathrm{C}$ at a rate of $4^{\circ} \mathrm{C} / \mathrm{min}$, and kept constant at $220^{\circ} \mathrm{C}$ for $10 \mathrm{~min}$ and then programmed to $240{ }^{\circ} \mathrm{C}$ at a rate of $1{ }^{\circ} \mathrm{C} / \mathrm{min}$. Split ratio was adjusted to 40:1. The injector temperature was set at $250{ }^{\circ} \mathrm{C}$. Mass spectra were recorded at $70 \mathrm{eV}$. Mass range was from $\mathrm{m} / z 35$ to 450 .

\section{GC analysis}

The GC analysis was carried out using an Agilent 6890N GC system. The FID (Flame Ionization Detector) temperature was $300^{\circ} \mathrm{C}$. To obtain the same elution order with GC-MS, simultaneous auto-injection was done on a duplicate of the same column applying the same operational conditions. Relative percentage amounts of the separated compounds were calculated from FID chromatograms. The analysis results are given in Table 1.

Identification of the EO components was carried out by comparison of their relative retention times with those of authentic samples or by comparison with their relative retention index (RRI) to a series of $n$-alkanes. Computer matching against commercial (Wiley GC/ MS Library, MassFinder 3 Library), 30,31 in-house "Başer Library of Essential Oil Constituents" created from genuine compounds and components of known oils, as well as MS literature data, ${ }^{32,33}$ was used for identification.

\section{Antiparasitic Studies}

\section{Sample Supply}

The study obtained Acanthamoeba castellani and Trichomonas vaginalis from Cumhuriyet University Parasitology laboratory, Leishmania infantum from Ege University Medical Parasitology Department and Eschericbia coli strains from Ordu University LiteratureScience Faculty Biology Department. Parasites were cultured to ensure continuity.

\section{Acanthamoeba culture}

\section{Non-nutrient Agar}

Eosin methylene blue (EMB) culture prepared according to the procedure was used to produce E. coli. The study used Page's amoeba saline solution. The prepared solution was placed in a $100 \mathrm{ml}$ flask and left in an autoclave at $121^{\circ} \mathrm{C}$ for $15 \mathrm{~min}$ and stored at $4^{\circ} \mathrm{C}$ until use.

\section{Preparation of Medium}

Agar of $1.5 \mathrm{~g}$ was heated and dissolved in $100 \mathrm{~mL}$ Page solution, autoclaved for $15 \mathrm{~min}$ at $121^{\circ} \mathrm{C}$ for $15 \mathrm{~min}$ and distributed to petri dishes. The cultures were stored at $4^{\circ} \mathrm{C}$ until use.

\section{Culture}

The prepared media were watered with $0.5 \mathrm{~mL}$ Page solution and 24-h E.coli strains were spread on the agar. Samples taken from $A$. castalleni strains were seeded on the medium. Seeded parasites were left for $72 \mathrm{~h}$ at $26^{\circ} \mathrm{C}$ and trophozoites were collected from the petri dishes without harm and washed using Page solution at $1500 \mathrm{~g}$ for $5 \mathrm{~min}$ in a centrifuge. To test the viability of trophozoites, $0.4 \%$ trypan blue was used and they were counted on a hemocytometer slide.

\section{Trichomonas vaginalis culture Cysteine-Peptone-Liver-Maltose (CPLM) Culture Method}

The CPLM medium liver extract mixture comprised $20 \mathrm{~g}$ Bacto liver powder mixed with $330 \mathrm{ml}$ distilled water. The mixture was left for $1 \mathrm{~h}$ at $50^{\circ} \mathrm{C}$ and then at $80^{\circ} \mathrm{C}$ for protein coagulation. Later it was strained through filter paper. Ringer solution was prepared by melting 2 Ringer tablets in $1000 \mathrm{~mL}$ distilled water. The liver extract and Ringer solution were mixed well together. This mixture has $32 \mathrm{~g}$ peptone, $16 \mathrm{~g}$ maltose, $2.4 \mathrm{~g} \mathrm{~L}$-cysteine $\mathrm{HCl}$ and $1.6 \mathrm{~g}$ Bacto agar added. The mixture was left in a water bath until the agar melted and was strained after the agar had fully melted. The strained mixture had $0.7 \mathrm{~mL} 0.5 \%$ methylene blue added. The prepared medium had $\mathrm{pH}$ set to $5.8-6$, was had $5 \mathrm{ml}$ each distributed to $125 \times 16 \mathrm{~mm}$ tubes and was sterilized for $20 \mathrm{~min}$ at $121^{\circ} \mathrm{C}$. For sterilization control a sample tube was left at $37^{\circ} \mathrm{C}$ for $24 \mathrm{~h}$ incubation. The tubes were stored at $+4{ }^{\circ} \mathrm{C}$ until seeding.

\section{Culture}

Under sterile conditions $1 \mathrm{~mL}$ inactivated human serum (left for half an $\mathrm{h}$ at $56^{\circ} \mathrm{C}$, inactivated human serum was stored in a deep freeze) was added to the medium. Diluted penicillin, streptomycin and triflucan of $1 \mathrm{ml}$ each was added to $1 \mathrm{~mL}$ physiologic serum and each tube had $0.2 \mathrm{~mL}$ of medication added under sterile conditions and then was left in an incubator at $37^{\circ} \mathrm{C}$. Two days later they were investigated for proliferation. Samples taken from the medium washed with sterile Ringer solution at $1500 \mathrm{~g}$ for $5 \mathrm{~min}$ in a centrifuge. To test the viability of trophozoites, $0.4 \%$ trypan blue was used and counted on a hemocytometer slide. 


\begin{tabular}{|c|c|c|c|}
\hline No & $\mathbf{R R I}^{\mathrm{a}}$ & Compound & $\%$ \\
\hline 1 & 1014 & Tricyclene & $0.2 \pm 0 b$ \\
\hline 2 & 1032 & $\alpha$-Pinene & $0.8 \pm 0$ \\
\hline 3 & 1035 & $\alpha$-Thujene & $0.3 \pm 0$ \\
\hline 4 & 1076 & Camphene & $4.73 \pm 0.05$ \\
\hline 5 & 1118 & $\beta$-Pinene & $0.5 \pm 0$ \\
\hline 6 & 1132 & Sabinene & $0.3 \pm 0$ \\
\hline 7 & 1188 & $\alpha$-Terpinene & $0.3 \pm 0$ \\
\hline 8 & 1203 & 2-Methyl butyl isobutyrate & $0.2 \pm 0$ \\
\hline 9 & 1213 & 1,8-Cineole & $25.53 \pm 0.21$ \\
\hline 10 & 1255 & $\gamma$-Terpinene & $0.7 \pm 0$ \\
\hline 11 & 1280 & p-Cymene & $2.73 \pm 0.05$ \\
\hline 12 & 1286 & 2-Methyl butyl 2-methyl butyrate & $0.5 \pm 0$ \\
\hline 13 & 1450 & trans-Linalool oxide (Furanoid) & $0.2 \pm 0$ \\
\hline 14 & 1474 & trans-Sabinene hydrate & $1.07 \pm 0.87$ \\
\hline 15 & 1532 & Camphor & $40.57 \pm 0.77$ \\
\hline 16 & 1553 & Linalool & $0.33 \pm 0.05$ \\
\hline 17 & 1556 & cis-Sabinene hydrate & $0.3 \pm 0$ \\
\hline 18 & 1571 & trans-p-Menth-2-en-1-ol & $0.6 \pm 0$ \\
\hline 19 & 1586 & Pinocarvone & $0.8 \pm 0$ \\
\hline 20 & 1591 & Bornyl acetate & $1.27 \pm 0.05$ \\
\hline 21 & 1611 & Terpinen-4-ol & $3.5 \pm 0.08$ \\
\hline 22 & 1638 & cis-p-Menth-2-en-1-ol & $0.47 \pm 0.05$ \\
\hline 23 & 1648 & Myrtenal & $0.37 \pm 0.05$ \\
\hline 24 & 1663 & cis-Verbenol & $0.53 \pm 0.19$ \\
\hline 25 & 1670 & trans-Pinocarveol & $0.73 \pm 0.05$ \\
\hline 26 & 1682 & $\delta$-Terpineol & $0.37 \pm 0.05$ \\
\hline 27 & 1683 & trans-Verbenol & $1.07 \pm 0.05$ \\
\hline 28 & 1706 & $\alpha$-Terpineol & $0.2 \pm 0$ \\
\hline 29 & 1709 & $\alpha$-Terpinyl acetate & $0.87 \pm 0.05$ \\
\hline 30 & 1719 & Borneol & $3.87 \pm 0.12$ \\
\hline 31 & 1725 & Verbenone & $0.77 \pm 0.05$ \\
\hline 32 & 1751 & Carvone & $0.3 \pm 0$ \\
\hline 33 & 1758 & cis-Piperitol & $0.23 \pm 0.05$ \\
\hline 34 & 1786 & ar-Curcumene & $0.1 \pm 0$ \\
\hline 35 & 1793 & $\alpha$-Campholene alcohol & $0.17 \pm 0.05$ \\
\hline 36 & 1802 & Cumin aldehyde & $0.3 \pm 0$ \\
\hline 37 & 1804 & Myrtenol & $0.1 \pm 0$ \\
\hline 38 & 1845 & trans-Carveol & $0.37 \pm 0.05$ \\
\hline 39 & 1864 & p-Cymen-8-ol & $0.3 \pm 0$ \\
\hline 40 & 1896 & cis- $p$-Mentha-1(7),8-diene-2-ol & $0.1 \pm 0$ \\
\hline 41 & 2008 & Caryophyllene oxide & $0.3 \pm 0.08$ \\
\hline 42 & 2144 & Spathulenol & $0.33 \pm 0.05$ \\
\hline 43 & 2257 & $\beta$-Eudesmol & $0.2 \pm 0$ \\
\hline 44 & 2316 & Caryophylla-2(12),6(13)-dien-5 $\alpha$-ol (=Caryophylladienol I) & $0.1 \pm 0$ \\
\hline \multirow[t]{2}{*}{45} & 2324 & Caryophylla-2(12),6(13)-dien-5 $\alpha$-ol (=Caryophylladienol II) & $0.2 \pm 0$ \\
\hline & & Total & $98.47 \pm 0.41$ \\
\hline
\end{tabular}

$a$ RRI Relative retention indices calculated against $n$-alkanes on the HP Innowax column; $b$ mean $\%$ calculated from Flame lonization Detector (FID) data \pm SD $(n=3)$. 


\section{Leishmania culture}

To ready-made RPMI-1640 medium, $10 \%$ fetal bovine serum added. The medium had 10,000 IU penicillin, $10 \mu \mathrm{g}$ streptomycin and $40 \mu \mathrm{g}$ triflucan added as antibiotics. Leishmania culture had samples taken with a sterile glass Pasteur pipette and these were seeded on medium and incubated at $25^{\circ} \mathrm{C}$. Four days later the medium was checked, if proliferation had occurred the study began. To test the viability of promastigotes, $0.4 \%$ trypan blue was used and they were counted on a hemocytometer slide.

\section{Preparation of essential oil concentrations}

Essential oil prepared with physiologic serum at concentrations of $32,16,8,4,2$ and $1 \mathrm{mg} / \mathrm{mL}$ and $200 \mu \mathrm{L}$ was distributed into sterile eppendorf tubes.

\section{Experimental stage}

Final concentrations were set to $20 \times 10^{6}$ trophozoite $/ \mathrm{mL}$ for $A$. castellani, $51 \times 10^{6}$ trophozoite $/ \mathrm{ml}$ for T. vaginalis and $45 \times 10^{6}$ trophozoite $/ \mathrm{ml}$ for L. infantum and these were added to the $200 \mu \mathrm{L}$ tubes and incubated at room temperature. The viability of the parasites was checked at certain times and noted. Tubes with no live cells identified had control seeding performed again and no proliferation was observed in any. Parasites without added essential oil were left in the same environment as controls. EO and control group were diluted with saline.

\section{Statistical Assessment}

Data firstly were subjected to logarithmic transformation to ensure the assumption of homogeneity of variance. To determine whether there was a significant difference between viability of the parasite species and dose administered, the transformed data had the repeated measures variance analysis and the Tukey multiple comparison test applied. The analysis results returned the data to their original form and present the research findings as $\mathrm{n}$, mean and standard deviation. The results were accepted as having significance level of $p \leq 0.05$. All statistical calculations were performed with the SPSS 22.0 V statistical packet program.

\section{RESULTS AND DISCUSSIONS}

In the study, the antiparasitic effect of $A$. ludoviciana$\mathrm{EO}$ on $T$. vaginalis, $A$. castellani and $L$. infantum was evaluated and the percentage yield of EO of A. ludoviciana flowering herb was calculated on a dry weight basis (0.092\%). The compounds of AL-EO were showed in Table 1.
Each measurement in the study was taken twice and the means were calculated. The repeated measures variance analysis Table for the viability levels of the parasite species according to dose and time is given in Table 2, with descriptive statistics (mean and standard deviation) given in Table 3.

When Table 2 is investigated, there was a significant difference determined in the viability of the parasites depending on time, parasite species and doses. Additionally, the effect of dose*time interaction was determined to have a significant effect on parasite viability. In this situation as the dose increased, it may be interpreted that the rate of reduction in parasite viability fell. Again, there was a reduction in parasite viability linked to time observed which is shown in Figures 1, 2 and 3. Additionally, the cause of the difference in parasite viability levels depending on parasite species and doses may be explained by the different rates of antiparasitic effect according to plant species.

When Table 3 is examined, it is observed that T. vaginalis was completely dead in the 48th h.

As seen in Table 3, as the concentration of EO increased, the viability rates of the parasites reduced. At the start of the experiment the concentration of $20 \times 10^{6}$ trophozoite/mL of $A$. castellani had final concentration in the control tube of $17 \times 10^{6}$ trophozoite $/ \mathrm{mL}$, the inital $51 \times 10^{6}$ trophozoite $/ \mathrm{mL}$ for T. vaginalis had final concentration in the control tube of $27 \times 10^{6}$ trophozoite $/ \mathrm{mL}$ and the inital $45 \times 10^{6}$ trophozoite $/ \mathrm{mL}$ for L. infantum had final concentration in the control tube of $45 \times 10^{6}$ trophozoite $/ \mathrm{mL}$.

In the study, the $64 \mathrm{mg} / \mathrm{mL}$ concentration of AL-EO inhibited the proliferation of $A$. castellani trophozoites in the first three $\mathrm{h}$ and had rapid effect with amoebicidal effect in the first $24 \mathrm{~h}$. Again, the $64 \mathrm{mg} / \mathrm{mL}$ concentration inhibited proliferation of the parasitic trophozoites of T. vaginalis in the first three $h$ and had rapid effect with anti-tricomonal effect in the first $8 \mathrm{~h}$. Additionally, the $64 \mathrm{mg} / \mathrm{mL}$ concentration of EO inhibited the proliferation of trophozoites of $L$. infantum in the first three $h$ and had rapid effect with antileishmanial effect in the first $14 \mathrm{~h}$.

When the Figures 1,2,3 are investigated, it is observed that the viability rates for the parasites effectively fell depending on dose.

To assess the viability rates of the parasites according to dose, the Tukey test was performed and results are given in Table 4.

When the Table 3 is examined, $64 \mathrm{mg} / \mathrm{ml}$ dose significantly reduced viability. The reductions in viability rates of the parasites with doses of $32 \mathrm{mg} / \mathrm{ml}, 16 \mathrm{mg} / \mathrm{ml}$ and 


\begin{tabular}{|c|c|c|c|c|c|}
\hline \multicolumn{7}{|c|}{ Table 2: Variance analysis table of parasite species according to time and dose. } \\
\hline Source of variance & $\begin{array}{c}\text { Type III Sum of } \\
\text { Squares }\end{array}$ & df & Mean Square & F & Sig. \\
\hline Time & 8.353 & 1 & 8.353 & 6.333 & 0.020 \\
\hline Time * parasite_species $^{\text {Sime * doses }}$ & 7.182 & 2 & 3.591 & 2.722 & 0.089 \\
\hline Time & 120.154 & 6 & 20.026 & 15.182 & $<0.001$ \\
\hline Time * parasite_species* doses & 49.678 & 12 & 4.140 & 3.138 & 0.011 \\
\hline Error (time) & 27.700 & 21 & 1.319 & & \\
\hline Parasite_species & 71.870 & 2 & 35.935 & 14.096 & $<0.001$ \\
\hline Doses & 505.789 & 6 & 84.298 & 33.068 & $<0.001$ \\
\hline Parasite_species * doses & 40.192 & 12 & 3.349 & 1.314 & 0.282 \\
\hline Error & 53.534 & 21 & 2.549 & & \\
\hline
\end{tabular}

\begin{tabular}{|c|c|c|c|c|c|c|c|c|c|c|c|}
\hline Parasites & $\begin{array}{c}\text { Dose } \\
(\mathrm{mg} / \mathrm{ml})\end{array}$ & \multicolumn{10}{|c|}{ Experimental periods } \\
\hline \multirow{9}{*}{ A. castellani } & \multirow{2}{*}{ AL-EO } & \multicolumn{2}{|c|}{$3 \mathrm{~h}$} & \multicolumn{2}{|c|}{$24 \mathrm{~h}$} & \multicolumn{2}{|c|}{$54 \mathrm{~h}$} & \multicolumn{2}{|c|}{$76 \mathrm{~h}$} & \multicolumn{2}{|c|}{$120 \mathrm{~h}$} \\
\hline & & Mean & $\mathrm{SD}$ & \multicolumn{2}{|c|}{ Mean } & Mean & SD & Mean & SD & 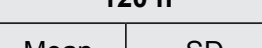 & SD \\
\hline & 1.0 & $19.5 \times 10^{6}$ & 1.44 & $9.5 \times 10^{6}$ & 1.08 & $8 \times 10^{6}$ & 1.00 & $1 \times 10^{6}$ & 1.00 & $1 \times 10^{6}$ & 1.00 \\
\hline & 2.0 & $17 \times 10^{6}$ & 1.54 & $8 \times 10^{6}$ & 1.17 & $5.5 \times 10^{6}$ & 1.14 & $1 \times 10^{6}$ & 1.00 & $1 \times 10^{6}$ & 1.00 \\
\hline & 4.0 & $5.5 \times 10^{6}$ & 1.14 & $5 \times 10^{6}$ & 1.00 & $4 \times 10^{6}$ & 3.55 & $0.5 \times 10^{6}$ & 17484.00 & $0.5 \times 10^{6}$ & 17484.00 \\
\hline & 8.0 & $5 \times 10^{6}$ & 1.00 & $4 \times 10^{6}$ & 1.00 & $4 \times 10^{6}$ & 1.00 & $2.5 \times 10^{6}$ & 17484.00 & $0.5 \times 10^{6}$ & 17484.00 \\
\hline & 16.0 & $4.5 \times 10^{6}$ & 1.17 & $3 \times 10^{6}$ & 1.63 & $2 \times 10^{6}$ & 1.00 & $0.5 \times 10^{6}$ & 17484.00 & $0.5 \times 10^{6}$ & 17484.00 \\
\hline & 32.0 & $4 \times 10^{6}$ & 1.00 & $2 \times 10^{6}$ & 1.00 & $2 \times 10^{6}$ & 2.17 & $0.5 \times 10^{6}$ & 17484.00 & $0.5 \times 10^{6}$ & 17484.00 \\
\hline & 64.0 & $1.0 \times 10^{6}$ & 1.00 & 0 & 1.00 & 0 & 1.00 & 0 & 1.00 & 0 & 1.00 \\
\hline \multirow{8}{*}{ T. vaginalis } & AL-EO & \multicolumn{2}{|c|}{$3 \mathrm{~h}$} & \multicolumn{2}{|c|}{$8 \mathrm{~h}$} & \multicolumn{2}{|c|}{$24 \mathrm{~h}$} & \multicolumn{2}{|c|}{$35 \mathrm{~h}$} & \multicolumn{2}{|c|}{$48 \mathrm{~h}$} \\
\hline & 1.0 & $25 \times 10^{6}$ & 2.17 & $16 \times 10^{6}$ & 2.07 & $7.5 \times 10^{6}$ & 1.10 & $2.4 \times 10^{6}$ & 3.55 & $1 \times 10^{6}$ & 17484.00 \\
\hline & 2.0 & $23 \times 10^{6}$ & 2.67 & $14 \times 10^{6}$ & 1.75 & $4.5 \times 10^{6}$ & 1.33 & $2.2 \times 10^{6}$ & 3.12 & $1 \times 10^{6}$ & 17484.00 \\
\hline & 4.0 & $14 \times 10^{6}$ & 4.65 & $8.5 \times 10^{6}$ & 2.17 & $2 \times 10^{6}$ & 2.67 & $1.5 \times 10^{6}$ & 1.63 & 0 & 1.00 \\
\hline & 8.0 & $14 \times 10^{6}$ & 4.50 & $6.3 \times 10^{6}$ & 1.91 & $2 \times 10^{6}$ & 2.67 & 0 & 1.00 & 0 & 1.00 \\
\hline & 16.0 & $11 \times 10^{6}$ & 4.54 & $4.4 \times 10^{6}$ & 1.17 & $1.5 \times 10^{6}$ & 1.63 & 0 & 1.00 & 0 & 1.00 \\
\hline & 32.0 & $10 \times 10^{6}$ & 4.16 & $2 \times 10^{6}$ & 1.00 & $1 \times 10^{6}$ & 2.17 & 0 & 1.00 & 0 & 1.00 \\
\hline & 64.0 & $1.5 \times 10^{6}$ & 1.63 & 0 & 1.00 & 0 & 1.00 & 0 & 1.00 & 0 & 1.00 \\
\hline \multirow{8}{*}{ L. infantum } & AL-EO & \multicolumn{2}{|c|}{$3 \mathrm{~h}$} & \multicolumn{2}{|c|}{$14 \mathrm{~h}$} & \multicolumn{2}{|c|}{$24 \mathrm{~h}$} & \multicolumn{2}{|c|}{$54 \mathrm{~h}$} & \multicolumn{2}{|c|}{$78 \mathrm{~h}$} \\
\hline & 1.0 & $10 \times 10^{6}$ & 1.33 & $8 \times 10^{6}$ & 1.38 & $6 \times 10^{6}$ & 1.00 & $4 \times 10^{6}$ & 1.00 & 0 & 1.00 \\
\hline & 2.0 & $10 \times 10^{6}$ & 1.00 & $7 \times 10^{6}$ & 1.00 & $3 \times 10^{6}$ & 1.63 & $3 \times 10^{6}$ & 1.00 & 0 & 1.00 \\
\hline & 4.0 & $10 \times 10^{6}$ & 1.00 & $4 \times 10^{6}$ & 1.00 & $2 \times 10^{6}$ & 1.00 & $0.5 \times 10^{6}$ & 17484.00 & 0 & 1.00 \\
\hline & 8.0 & $5 \times 10^{6}$ & 1.33 & $4 \times 10^{6}$ & 1.44 & $1 \times 10^{6}$ & 1.00 & 0 & 1.00 & 0 & 1.00 \\
\hline & 16.0 & $4 \times 10^{6}$ & 1.44 & $1 \times 10^{6}$ & 1.00 & 0 & 1.00 & 0 & 1.00 & 0 & 1.00 \\
\hline & 32.0 & $2 \times 10^{6}$ & 1.00 & $0.5 \times 10^{6}$ & 17484.00 & 0 & 1.00 & 0 & 1.00 & 0 & 1.00 \\
\hline & 64.0 & $1.0 \times 10^{6}$ & 1.00 & 0 & 1.00 & 0 & 1.00 & 0 & 1.00 & 0 & 1.00 \\
\hline
\end{tabular}




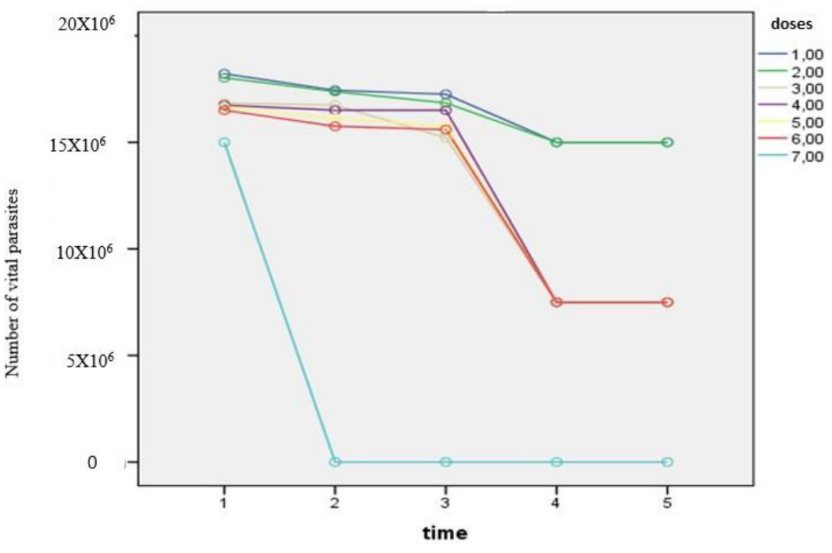

Figure 1: Viability graph of $\boldsymbol{A}$. castallani according to time and dose.

Doses: $1=1 \mathrm{mg} / \mathrm{ml}, 2=2 \mathrm{mg} / \mathrm{ml}, 3=4 \mathrm{mg} / \mathrm{ml}, 4=8 \mathrm{mg} / \mathrm{ml}, 5=16$ $\mathrm{mg} / \mathrm{ml}, 6=32 \mathrm{mg} / \mathrm{ml}, 7=64 \mathrm{mg} / \mathrm{ml}$

Time: $1=3 \mathrm{~h}, 2=24 \mathrm{~h}, 3=54 \mathrm{~h}, 4=76 \mathrm{~h}, 5=120 \mathrm{~h}$

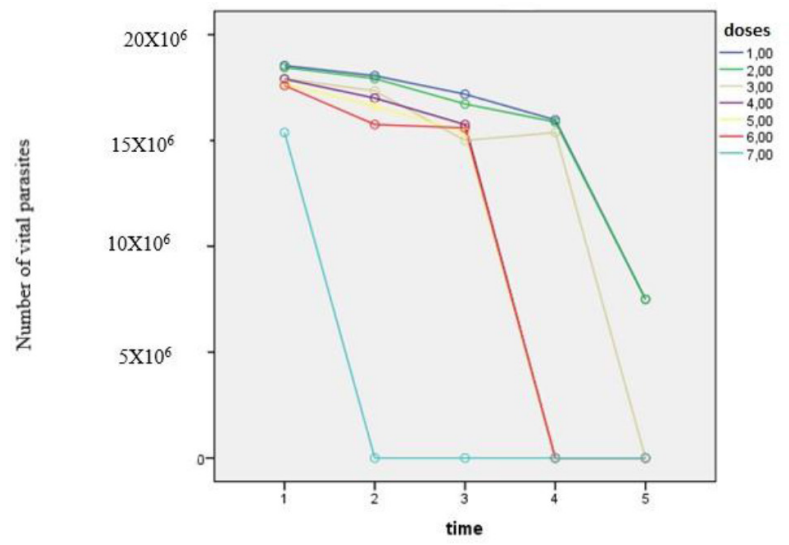

Figure 2: Viability graph of $T$. vaginalis according to time and dose.

Doses: $1=1 \mathrm{mg} / \mathrm{ml}, 2=2 \mathrm{mg} / \mathrm{ml}, 3=4 \mathrm{mg} / \mathrm{ml}, 4=8 \mathrm{mg} / \mathrm{ml}, 5=16$ $\mathrm{mg} / \mathrm{ml}, 6=32 \mathrm{mg} / \mathrm{ml}, 7=64 \mathrm{mg} / \mathrm{ml}$

Time: 1=3 h, 2=8 h, 3=24 h, 4=35 h, 5=48 h.

\section{Table 4: Viability values for parasites according to} dose.

\begin{tabular}{|c|c|c|c|c|c|}
\hline \multirow{2}{*}{ doses } & \multirow{2}{*}{$\mathbf{N}$} & \multicolumn{4}{|c|}{ Subset } \\
\cline { 3 - 6 } & & $\mathbf{d}$ & $\mathbf{c}$ & $\mathbf{b}$ & $\mathbf{a}$ \\
\hline 7.00 & 6 & 1.2100 & & & \\
\hline 6.00 & 6 & & 3.6015 & & \\
\hline 5.00 & 6 & & 3.8573 & 3.8573 & \\
\hline 4.00 & 6 & & 4.3630 & 4.3630 & \\
\hline 3.00 & 6 & & & 4.9792 & 4.9792 \\
\hline 2.00 & 6 & & & & 6.0177 \\
\hline 1.00 & 6 & & & & 6.0922 \\
\hline Sig. & & 1.000 & 0.533 & 0.141 & 0.147 \\
\hline
\end{tabular}

Means for groups in homogeneous subsets are displayed. Based on observed means. The error term is Mean Square (Error) $=.510$.

a. Uses Harmonic Mean Sample Size $=6.000$.

b. The group sizes are unequal. The harmonic mean of the group sizes is used. Type I error levels are not guaranteed.

c. Alpha $=.05$

Doses: $1=1 \mathrm{mg} / \mathrm{ml}, 2=2 \mathrm{mg} / \mathrm{ml}, 3=4 \mathrm{mg} / \mathrm{ml}, 4=8 \mathrm{mg} / \mathrm{ml}, 5=16 \mathrm{mg} / \mathrm{ml}, 6=32 \mathrm{mg} / \mathrm{ml}$, $7=64 \mathrm{mg} / \mathrm{ml}$

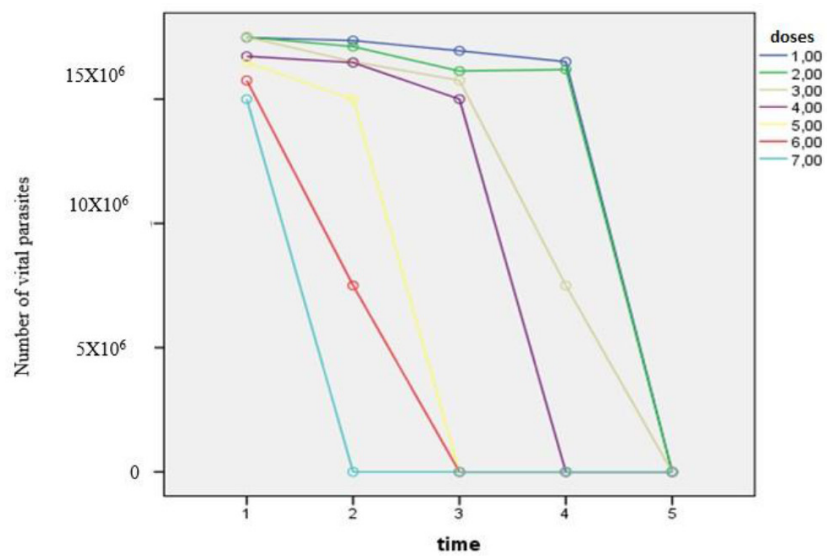

Figure 3: Infantum according to time and dose.

Doses: $1=1 \mathrm{mg} / \mathrm{ml}, 2=2 \mathrm{mg} / \mathrm{ml}, 3=4 \mathrm{mg} / \mathrm{ml}, 4=8 \mathrm{mg} / \mathrm{ml}, 5=16$ $\mathrm{mg} / \mathrm{ml}, 6=32 \mathrm{mg} / \mathrm{ml}, 7=64 \mathrm{mg} / \mathrm{ml}$

Time: 1=3 h, 2=14 h, 3=24 h, 4=54 h, 5=78 h.
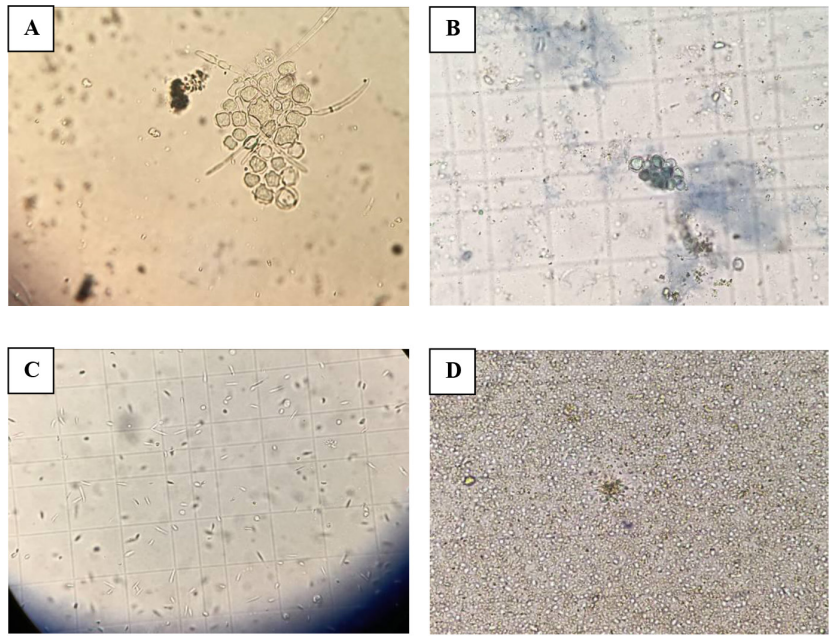

$\mathbf{E}$

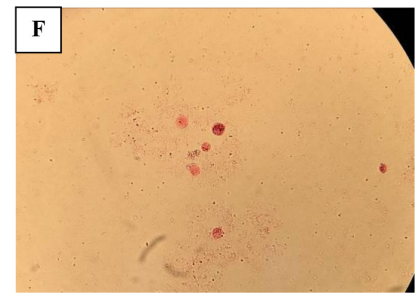

Figure 4: A. Viable Acanthamoeba cyst; B. Image of died Acanthamoeba after treatment with metilen blue; C. Viable Leishmania promastigot; D. Image of died Leishmania promastigot after treatment with metilen blue; E. Viable Trichomonas trophozoit; F. Image of died Trichomonas trophozoit after treatment with $0.1 \%$ eosin $(x 40)$.

$8 \mathrm{mg} / \mathrm{ml}$ were similar. The weakest effect on viability was found for doses of $1 \mathrm{mg} / \mathrm{ml}$ and $2 \mathrm{mg} / \mathrm{ml}$. The antiparasitic efficacy of AL-EO was showed in Figure 4. Literature information showed that for Leishmaniasis treatment in addition to different anti-leismanial agents like five valuable antimony compounds, amphotericin B deoxycholate, miltefosine, paromomycin, sitamaquine, 
azole and pentamidine, thermotherapy and cryotherapy applications may be used. ${ }^{34-36}$ The efficacy of the five valuable antimony compounds used for treatment is reported to be above $90 \%$, though rare local and systemic side effects like myalgia, arthralgia, stomach pain, hepatitis, pancreatitis and increases in a variety of laboratory values have been reported. ${ }^{36}$

When resistance to antimony compounds develops, for Visseral leishmaniasis treatment intravenous or intramuscular amphotericin B is used. As amphotericin B displays broad distribution through the body, it has side effects like infusion reactions, nephrotoxicity, hypokalemia and myocarditis and patients must be admitted for 4-5 weeks. ${ }^{34}$

The toxic side effects of anti-leishmanial medications used for treatment and the development of resistance of the parasite to these medications have led to studies related to definition and formulation of new molecules to date. ${ }^{37}$ Different studies have been completed; ${ }^{12-18}$ from a study showing the anti-leishmanial activity of ethanol extracts from Allium sativa (garlic) and Azadiracbta indica (Neem), locally used for treatment of Cutaneous leishmaniasis in the Sudan, had no significant difference when compared to pentostam, ${ }^{16}$ to studies emphasizing that the anti-leishmanial efficacy on promatigotes and amastigotes of Leishmania tropica was higher compared to two antibiotics in the macrolid group of azithromycin and clarithromycin. ${ }^{38}$ The AL-EO presented in this study can be considered for use as an antileishmanial.

Untill now, different researchers have reported plant extracts or essential oils with amoebicidal effects such as Thymus sipyleus Boiss. subsp. sipyleus Boiss. var. sipyleus L. at $32.0 \mathrm{mg} / \mathrm{mL},{ }^{39}$ Trigonella foenumgraecum L. at $400 \mathrm{mg} / \mathrm{mL},{ }^{40}$ Peucedanum caucasicum (Bieb.) C. Koch., P. palimbioides Boiss., P. chryseum Boiss. et Heldr. and P. longibracteolatum Parolly and Nordt at $32 \mathrm{mg} / \mathrm{mL},{ }^{41}$ Origanum syriacum L. and O. laevigatum Boiss. at $32.0 \mathrm{mg} / \mathrm{mL} .{ }^{42}$ Additionally, they reported the doses used were not toxic. The AL-EO presented in this study may be used as an antiamoebicidal. Treatment of $T$. vaginalis uses 5-nitroimidazole medications. However, due to many resistant isolates, research into new therapeutic medications has gained importance. In this way, different medications have been trialed researching plants and metabolites. ${ }^{43}$ Fernandes et. al. used 29 diluted extracts from plants as antiparasitics and reported four plant extracts showed tricomonidal efficacy. ${ }^{44}$ These plants were Securidaca longepedunculata Fresen. (Polygalaceae, $0.10 \mathrm{mg} / \mathrm{mL}$ ), Solanum aculeastrum Dun. (Solanaceae, $1.06 \mathrm{mg} / \mathrm{mL}$ ), Piper kapense L.f. (Piperaceae, $11.19 \mathrm{mg} / \mathrm{mL}$ ) and
Cassine transvaalensis (Burtt. Davy) Codd (Celastraceae, $9.69 \mathrm{mg} / \mathrm{mL}$ ). Ivanescu et. al. reported that the main metabolite of Artemisinin of dihydroartemisinin was an antiparasitic medication against Plasmodium, Schistosoma, Toxoplasma, Trichomonas vaginalis, Leishmania and Giardia lintestinalis. ${ }^{45}$ Moon et. al. reported that two essential oils derived from Lavandula angustifolia Mill. and Lavandula $\times$ intermedia were antiparasitic against Giardia intestinalis, Trichomonas vaginalis and the fish pathogen Hexamita inflata. ${ }^{46}$ The AL-EO presented in this study is considered for use as an antitrichomonal.

In the literature, studies on the EO composition of some Artemisia species were reported and these oils were found to have high antiparasitic activity. ${ }^{47,48}$ According to results, Artemisia species were divided into two sub-groups with regard to EO composition; the first group was characterized by the presence of camphor and 1.8-cineole and the second group included mostly $\alpha$-thujone. These essential oils possess antiparasitic efficiency. Also, these components are known to have antiparasitic efficiency. ${ }^{47,49,50}$

\section{CONCLUSION}

In this study, it was revealed for the first time that EO of $A$. ludoviciana was effective against three important parasites. It is thought that this strong efficacy is due to the camphor and 1,8-cineole identified as the main components of the oil. For AL-EO to be used as medication, there is a need for in vitro macrophage cultures for efficacy against Leishmania amastigotes and in vivo experimental animal model control studies. Again, it is concluded there is a need for advanced studies to research the antitrichomonal and amoebicidal efficacy. At the same time this oil, with determined antiprotozoal activity, is identified to require active molecule purification and clarification to research the cytotoxic mechanism.

\section{ACKNOWLEDGEMENT}

This study was supported by the Erciyes University Scientific Research Foundation (Kayseri, Turkey) [Project number: THD-2016-6590]. We would like to thank for Leishmania infantum strains to Prof. Dr. Yusuf ÖZBEL and Prof. Dr. Seray TÖZ (Ege University), and for $A$. castellani strains to thank Prof. Dr. Serpil DEĞERLI (Cumhuriyet University) and also Biologist Necati ÖZPINAR (Cumhuriyet University) for Trichomonas vaginalis strains. Authors would like to thank Zeytinburnu Medicinal Plant Garden (Istanbul, Turkey) for supply $A$. ludoviciana culture form. 


\section{CONFLICT OF INTEREST}

The authors declare that they have no conflict of interest.

\section{ABBREVIATIONS}

AL: Artemisia ludoviciana; EO: Essential oil; RRI: Relative retention indices; FID: Flame Ionization Detector; GC-MS: Gas chromatography-mass spectrometry; CPLM: Cysteine-Peptone-Liver-Maltose; GAE: Granulamatous amoebic encephalitis; VL: Visceral leishmaniasis; CL: Cutaneous leishmaniasis; MAVA: maleic anhydride-co-vinyl acetate.

\section{REFERENCES}

1. Anthony JP, Fyfe L, Smith H. Plant active components-a resource for antiparasitic agents? Trends Parasitol. 2005;21(10):462-8.

2. Abad MJ, Bedoya LM, Apaza L, Bermejo P. The Artemisia L. genus: a review of bioactive essential oils. Molecules. 2012;17(3):2542-66.

3. Güner A, Aslan S, Ekim T, Vural M, Babaç MT (eds.). Türkiye Bitkileri Listesi (Damarlı Bitkiler). Nezahat Gökyiğit Botanik Bahçesi ve Flora Araştırmaları Derneği Yayını, İstanbul. 2012.

4. Zavala-Sanchez MA, Pérez-Gutiérrez S, Pérez-González C, SánchezSaldivar D, Arias-García L. Antidiarrhoeal activity of nonanal, an aldehyde isolated from Artemisia ludoviciana. Pharm Biol. 2002;40(4):263-8.

5. Lopes-Lutz D, Alviano DS, Alviano CS, Kolodziejczyk PP. Screening of chemical composition, antimicrobial and antioxidant activities of Artemisia essential oils. Phytochemistry. 2008;69(8):1732-8.

6. Fernández SS, Guerra MC, Cárdenas BD, Villarreal JV, Treviño LV. in vitro antiprotozoal activity of the leaves of Artemisia ludoviciana. Fitoterapia. 2005;76(5):466- 8

7. Malagon F, Vazquez J, Delgado G, Ruiz A. Antimalaric effect of an alcoholic extract of Artemisia ludoviciana mexicana in a rodent malaria model. Parassitol. 1997;39(1):3-7.

8. WHO: Expert Committee. Control of the Leishmaniasis. Geneva. 2010.

9. Ministry of Health Turkey Public Health Institution. [online] 2016Feb. Available from:http://www.thsk.gov.tr/dosya/birimler/strateji_db/dokumanlar/ faaliyet_raporu/2014_fa aliyet_raporu.pdf.

10. Bekhit AA, Haimanot T, Hymete A: Evaluation of some $1 \mathrm{H}$-pyrazole derivatives as a dual acting antimalarial and anti-leishmanial agents. Pak J Pharm Sci. 2014;27(6):1767-73.

11. De Araújo MV, de Souza PS, de QueirozAC, da Matta CB, Leite AB, DA Silva $\mathrm{AE}$, et al. Synthesis, leishmanicidal activityandtheoretical evaluationsof a series of substituted bis-2-hydroxy-1,4- naphthoquinones. Molecules. 2014;19(9):15180-95.

12. Dos Santos AO, Ueda-Nakamura T, Dias Filho BP, da Veiga Junior VF, Nakamura CV. Copaibaoil: An alternativeto development of new drugs against leishmaniasis. Evid Based Complement Alternat Med. 2012;2012.

13. Pourmohammadi B, Motazedian MH, Handjani F, Hatam G, Habibi S, Sarkari B. Glucantime efficacy in the treatment of zoonotic cutaneous leishmaniasis. Southeast Asian J Trop Med Public Health. 2011;42(3):502-8.

14. Kazemi-Rad E, Mohebali M, Khadem-Erfan MB, Saffari M, Raoofian R, Hajjaran $\mathrm{H}$, et al. Identification of antimony resistance markers in Leishmania tropica field isolatest hrough a cDNA- AFLP approach. Exp Parasitol. 2013;135(2):344-9.

15. Barbosa TP, Sousa SC, Amorim FM, Rodrigues YK, de Assis PA, Caldas JP, et al. Design, synthesis and antileishmanial in vitro activity of newseries of chalcones-like compounds: A molecular hybridization approach. Bioorg Med Chem. 2011;19(14):4250-6.

16. Khalid FA, Abdalla NM, Mohomed HEO, Toum AM, Magzoub MMA, Ali MS. Treatment of cutaneous leishmaniasis with some local Sudanese plants (Neem, Garad and Garlic). Turkiye Parazitol Derg. 2004;28(3):129-32.

17. Efstathiou A, Gaboriaud-Kolar N, Smirlis D, Myrianthopoulos V, Vougogiannopoulou K, Alexandratos A, et al. An inhibitor- driven study for enhancing the selectivity of indirubin derivatives towards leishmanial glycogen synthasekinase-3 over leishmanial cdc2-related protein kinase 3. Parasit Vectors. 2014;7(1):234.

18. Mowbray CE,Braillard S, Speed W, Glossop PA, Whitlock GA, Gibson KR, et al. Novel amino-pyrazole ureas with potent in vitro and in vivo antileishmanial activity. J Med Chem. 2015;58(24):9615-24.

19. Karaman U, Atambay M, Yazar S, Daldal N. Kadınlarda Trichomonas vaginalis'in Çeşitli Sosyal Değişkenler Açısından Yaygınlığının İncelenmesi (Malatya İli Örneği). Turkiye Parazitol Derg. 2006;30(1):11-5.

20. Girginkardeşler N, Limoncu E, Ok ÜZ, Özbilgin A. Trichomonas vaginalis'in semen sıvısı ve idrarda yaşam süresi. Turkiye Parazitol Derg. 1996;20(3-4): 345-8.

21. Balcı O, Çapar M. Vaginal Enfeksiyonlar. J Turk Soc Obstet Gynecol. 2005;2(5):14-20.

22. Yereli K, Balcıoğlu C, Değerli K, Sungurtekin Ü, Kilimcioğlu AA, Daldal N, et al. Evaluation of Trichomonas vaginalis incidence and Secnidazole Treatment in Women with Vaginal Discharge. Türkiye Parazitol Derg. 1997;21(2):141-4.

23. Özçelik S, Coşkun KA, Yünlü Ö, Alim A, Malatyalı E. The prevalence, isolation and morfotyping of potentially pathogenic free-living amoebae from tap water and environmental water sources in Sivas. Türk Parazitol Derg. 2012;36(4):198-203.

24. Chan LL, Mak JW, Low YT, Koh TT, Ithoi I, Mohamed SM. Isolatin and characterization of Acanthamoeba spp. from air-conditioners in Kuala Lumpur, Malaysia. Acta Tropica. 2011;117(1):23-30.

25. Thomas JM, Ashbolt NJ. Do Free-Living Amoebae in treated drinking water systems present an emerging health risk? Environ Sci Technol. 2010;45(3):860-9.

26. Coşkun KA, Özçelik S, Tutar L, Elaldı N, Tutar Y. Isolation and identification of Free-Living Amoebae from tap water in Sivas, Turkey. Biomed Res Int. 2013;2013:675145

27. Saygı G, Polat Z. Özgür Yaşayan Amipler ve Neden Oldukları Parazitozlar (Primer Amibik Meningoensefalit-Granülomatöz Amibik Ensefalit-Keratit. C Ü Tıp Fakültesi Dergisi. 2003;25(3):140-9.

28. Sharma S, Garg P, Rao GN. Patient characteristics, diagnosis, and treatment of non- contact lens related Acanthamoeba keratitis. $\mathrm{Br} \mathrm{J}$ Ophthalmol. 2000;84(10):1103-8.

29. Ertabaklar H, Dayanır V, Apaydın P, Ertuğ S, Walochnik J. Olgu Sunumu: Acanthamoeba keratiti. Türkiye Parazitol Derg. 2009;33(4):283-5.

30. McLafferty FW, Stauffer DB. The Wiley/NBS Registry of Mass Spectral Data. J Wiley and Sons, New York. 1989.

31. Koenig WA, Joulain D, Hochmuth DH. Terpenoids and Related Constituents of Essential Oils. MassFinder 3, Hamburg:Germany. 2004.

32. Joulain D, Koenig WA. The Atlas of Spectra Data of Sesquiterpene Hydrocarbons. EB- Verlag: Hamburg. 1998.

33. ESO 2000. The Complete Database of Essential Oils. Boelens Aroma Chemical Information Service, The Netherlands. 1999.

34. Sundar S, Chakravarty J. Leishmaniasis: an update of current pharmacotherapy. Expert Opin Pharmacother. 2013;14(1):53-63.

35. Monge-Maillo B, Lopez-Velez R. Therapeutic options for visceral leishmaniasis. Drugs. 2013;73(17):1863-88.

36. Yeşilova $Y$, Turan E, Altın Sürücü H, Aksoy M, Özbilgin A. Sistemik lipozomal amfoterisin B ttedavisine cevap veren kutanöz leishmaniasis olgusu. Turk Parazitol Derg. 2015;39:63-5.

37. Corral MJ, González E, Cuquerella M, Alunda JM. Improvement of 96-well microplate assay for estimation of cell grow than inhibition of Leishmania with alamar blue. J Microbiol Methods. 2013;94(2):111-6

38. Balcıoğlu IC, Ok ÜZ, Özbel Y, Girginkardeşler N, Özbilgin A. The in vitro effects of azithromycin and clarithromycin on promastigotes and amastigotes of Leishmania tropica. Kafkas Univ Vet Fak Derg. 2012;18(Suppl.-A): A115-A120

39. Polat ZA, Tepe B and Vural A. In-vitro effectiveness of Thymus sipyleus subsp. sipyleus var. sipyleus on Acanthamoeba castellanii and its cytotoxic potential on corneal cells. Parasitol Res. 2007;101(6):1551-5.

40. Dodangeh S, Niyyati M, Kamalinejad M. AntiAcanthamoeba Activities of Chloroformic Fractions of Trigonella foenum-graecum (Seed) and Their Cytotoxity on Mice Macrophage Cell. Novel Biomed. 2015;3(4):182-8. 
41. Malatyali E, Tepe B, Degerli S, Berk S, Akpulat HA. In-vitro amoebicidal activity of four Peucedanum species on Acanthamoeba castellanii cysts and trophozoites. Parasitol Res. 2012;110(1):167-74.

42. Degerli S, Tepe B, Celiksoz A, Berk S and Malatyali E. In-vitro amoebicidal activity of Origanum syriacum and Origanum laevigatum on Acanthamoeba castellanii cysts and trophozoites. Exp Parasitol. 2012;131(1):20-4.

43. Frasson AP, dos Santos O, Duarte M, da Silva Trentin D, Giordani RB, da Silva AG, et al. First report of anti-Trichomonas vaginalis activity of the medicinal plant Polygala decumbens from the Brazilian semi-arid region, Caatinga. Parasitol Res. 2012;110(6):2581-7.

44. Fernandes L, Van Rensburg CEJ, Hoosen AA, Steenkamp V. in vitro activity of medicinal plants of the Venda region, South Africa, against Trichomonas vaginalis. South Afr J Epidemiol Infect. 2008;23(2):26-8.

45. Ivanescu B, Miron A, Corciova A. Sesquiterpene Lactones from Artemisia Genus: Biological Activities and Methods of Analysis. J Anal Methods Chem. 2015:247685

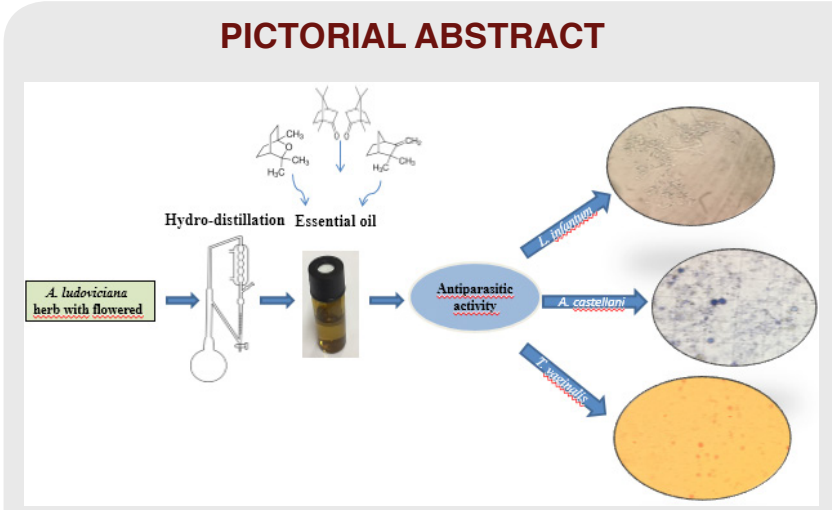

46. Moon T, Wilkinson JM, Cavanagh HM. Antiparasitic activity of two Lavandula essential oils against Giardia duodenalis, Trichomonas vaginalis and Hexamita inflata. Parasitol Res. 2006;99(6):722-8.

47. Yıldız K, Basalan M, Duru Ö, Gökpinar S. Antiparasitic efficiency of Artemisia absinthium on Toxocara cati in naturally infected cats. Türkiye Parazitol Derg. 2011;35(1):10.

48. Ivarsen E, Fretté X, Christensen KB, Engberg RG, Thøfner I, Liebhart D, et al. Antibacterial and antiparasitic effect of extracts from the aerial parts of Artemisia annua and identification of possible bioactive compounds. In Nordic Natural Products Conference (NNPC). 2011;35(1):10.

49. Allen PC, Lydon J, Danforth HD. Effects of components of Artemisia annua on coccidian infections in chickens. Poult Sci. 1997;76(8):1156-63.

50. Deans SG, Kennedy Al. Artemisia absinthum. In: Wright CW (ed) Artemisia. Taylor and Francis. 2002.

\section{SUMMARY}

In this study, it was found to effect Acanthamoeba castellani, Leishmania infantum and Trichomonas vaginalis of Artemisia ludoviciana essential oil for the first time. It is assume that this potent efficacy is due to the camphor and 1,8-cineole identified as the main components of the oil. It is a need for advanced studies, such as edited some in vitro and in vivo experimental models, for research to strong antiprotozoal effects of A. ludoviciana oil.

\section{About Authors}

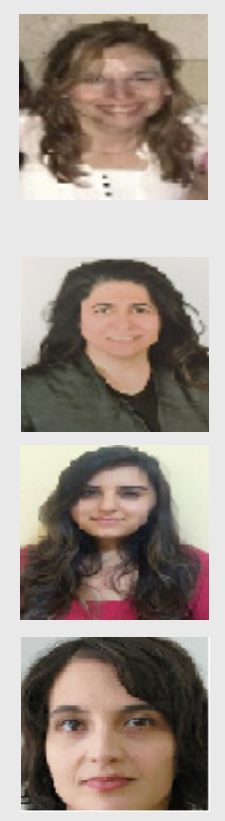

Assistant Dr. Ayșe Baldemir is the Head of Dept of Pharmaceutical Botany in Erciyes University, Faculty of Pharmacy. She is gained her doctorate degree in Ankara University Pharmacy Faculty in 2010. She has continued to works in collaboration with the Dept. of Pharmaceutical Microbiology, Pharmaceutical Toxiology and Analytical Chemistry in University of Erciyes. She continues to work on plant anatomy, morphology, potential biological activities of plant extract/active components and recently on green chemistry.

Assistant Prof. Ülkü Karaman is Assistant professor Ordu University Faculty of Medicine, Department of Medical Parasitology, Ordu, Turkey. She has copleted he Ph.D. from Department of Medical Parasitology. Her area of research interest is medical parasitology and microbiolog. He has about 19 years working in health science

Gamze Kacmaz graduated from Giresun University Biology Department in 2014. Giresun University, Graduate School of Health Sciences, Department of Medical Microbiology. The study area is Medical Parasitology.

Betul Demirci, PhD, MSc, Pharm., Professor of Pharmacognosy, works since 1992 on natural products, and chromatography, isolation and analytics of volatiles as well as essential oils from the point of phytomedicines and phytotherapeuticals.

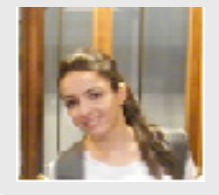

Selen ligun is a Research asistant at Erciyes University, Faculty of Pharmacy, Pharmaceutical Botany Department in Turkey since 2011. She completed her graduate in Dept. of Biology at 2009 in Erciyes University. She is a Ph. D student at Ankara University, Faculty of Pharmacy, Pharmaceutical Botany Department. Research areas are Pharmaceutical Botany and Pharmacognosy

Cite this article: Baldemir A, Karaman Ü, Ilgün S, Kaçmaz G, Demirci B. Antiparasitic Efficacy of Artemisia ludoviciana Nutt. (Asteraceae) Essential Oil for Acanthamoeba castellanii, Leishmania infantum and Trichomonas vaginalis. Indian J of Pharmaceutical Education and Research. 2018;52(3):416-25. 